\title{
Leaf morphological variation among paper birch (Betula papyrifera Marsh.) genotypes across Canada
}

\author{
Anjala Pyakurel ${ }^{\star}$, Jian R. Wang \\ Faculty of Natural Resources Management, Lakehead University Thunder Bay, Thunder Bay, Canada; \\ *Corresponding Author: apyakure@lakeheadu.ca
}

Received 25 April 2013; revised 31 May 2013; accepted 8 July 2013

Copyright (C) 2013 Anjala Pyakurel, Jian R. Wang. This is an open access article distributed under the Creative Commons Attribution License, which permits unrestricted use, distribution, and reproduction in any medium, provided the original work is properly cited.

\begin{abstract}
Variations in leaf morphological characteristics have been extensively studied at both inter- and intraspecific levels although not explicitly on paper birch (Betula papyrifera Marsh). Paper birch populations might have considerable genotypic and leaf morphological variations that have allowed them to inhabit wide environmental gradients. In this study, we analyzed variations in leaf morphological characteristics in 23 paper birch populations collected across Canada and grown in a greenhouse. Furthermore, we examined whether the variations in leaf morphological characteristics observed were related to the climate of the population's origin. We found significant genotypic differences in all leaf morphological characteristics $(p<0.05)$ measured among the birch populations. Thus, we expected that the morphological variations in birch might be related to natural diversity in birch populations due to environmental differences at habitat origin. Principal component analysis (PCA) reduced thirteen leaf morphological variables to five principal components (PC) explaining $84.74 \%$ of the total variance in the original data. PCs accumulated with specific leaf area, petiole and leaf width were positively related to latitudinal, longitudinal, and elevational gradients at the population's origin. Unpredictably, these PCs were significantly negatively correlated to precipitation and aridity index at the origin. Thus, we analyzed if correlations within leaf morphological characteristics had supported the birch populations to acclimate and produce unpredictable relations with the environment of origin. Our results showed that the populations originated in limited precipitation (during growing
\end{abstract}

season) had large leaf width and petiole size but low leaf hairs on adaxial surface. Thus, all these leaf morphological features provide a basis for the birch to reduce water loss from leaves and balance water use efficiency in reduced precipitation. Furthermore, the leaf characteristics measured may also include phenotypic plasticity of the birch as an acclimation to the environment as in the greenhouse.

Keywords: Morphological Variation; Leaf Size; Leaf Shape; Petiole Size; Leaf Hairiness; Climatic

Variables; Paper Birch

\section{INTRODUCTION}

Plant species inhabiting environmental gradients exhibit genotypic and phenotypic difference [1,2]. It has been suggested that plants respond to these environmental changes by allocating biomass among several plant organs in order to capture optimum light, water, nutrient and carbon dioxide, and as a strategy to maximize growth rate [3]. Thus, plant develops the ability, often referred to as phenotypic plasticity, to produce different phenotypes as a response to abiotic stress [4]. Therefore, the characterization of geographical pattern of morphological variation in natural plant populations suggests possible patterns of genotypic variation and plastic responses to environmental gradients $[5,6]$. These plasticity responses are expressed at different levels such as plant morphology, anatomy, physiology and growth.

Leaves are the important organs for plant production and are sensitive to the inhabiting environment [7]. Leaf morphological variations for plants growing in contrasting habitats have long been studied in numerous species such as Azadirachta indica [8], Eucalyptus sideroxy-lon [9], and Quercus rugosa [6]. There previous studies suggest that small leaves track air temperature closely, whereas large leaves suffer from overheating when water is 
limited $[9,10]$. Thus, smaller leaves are often associated with habitats at higher elevation with increased temperature [11] where moisture [12] and aridity index [13] are limited. Furthermore, small leaves are characterized by a decrease in specific leaf area (SLA) and an increase in leaf hairiness. It is suggested that thick (low SLA) leaves can better withstand wilting in comparison to thinner leaves in dry and hot environments $[9,14]$. Additionally, leaf hairs can influence leaf water relations by increasing boundary layer resistance $[15,16]$ and decreasing leaf temperature by reflecting radiation [17]. Consequently, increased leaf hairs in hot and arid habitats have significant influence in reducing solar radiation, leaf temperature and transpirational losses [18-20].

Alternatively, narrower leaves are viewed as plant's adaptation to dry and hot environments, while wider leaves are an adjustment to wet and cold environments. It has been established that narrower leaves, compared to wider leaves, provide structural reinforcement to withstand wilting in hot, sunny and dry environments [21-23]. Similarly, petiole length influences leaf arrangement, affecting light interception efficiency under different circumstances [24]. Previous studies have shown that petiole size increase in larger leaves along decreasing drought gradients, which probably reflected the need for mechanical strengthening to support large leaves $[25,26]$. However, within the deciduous broadleaved trees, petiole size increases with drought which may act as a mechanical support to promote leaf cooling [27].

The majority of studies on leaf morphological variation in response to climatic factors have included species inhabiting different environments. Results of these studies showed remarkable leaf morphological variation in relation to their inhabiting environments [6,28-30]. For example, species from the genus Betula often show significant differences in leaf morphology such as leaf size [31-34] and shape [31,32,34]. Most of these studies on leaf morphological response to environmental factors have either included comparative studies among multiple species [22] or species inhabiting different locations along environmental gradient $[21,22,35]$. Therefore, it is important to determine whether leaf morphology differ in wide-ranging pioneer species like paper birch (Betula papyrifera Marsh.) grown in a uniform environment. To our knowledge, no studies have focused on leaf morphological variations of the birch populations grown in a uniform environment.

Paper birch (Betula papyrifera Marsh.), the most widely distributed pioneer tree species in Canada [36], is an ecologically and economically important hardwood species. The interaction of genetic diversity and wide environmental range within its distribution may have resulted in morphological variation like in other species
[9,37]. In this study, we examined if leaf morphology varies among paper birch populations collected across Canada and if the variation in these leaf morphological characteristics is related to the latitude, longitude, elevation and climates of origin. Based on geographic and climatic differences at a population's origin, we tested the following hypotheses: 1) leaf morphological characteristics vary among paper birch populations grown in the same environment; 2) leaf morphological characteristics exhibit consistent multivariate patterns related to environmental variables at a population's origin 3) leaf size, maximum width and perimeter would increase in higher precipitation and aridity index but would decrease with temperature, longitude, latitude and elevation gradients; 4) specific leaf area and maximum width index would increase with increasing precipitation and aridity index whereas it would decrease along temperature, longitude, latitude and elevation gradients; 5) petiole size, petiole index and aspect ratio would decrease with reducing precipitation and aridity index but would increase with temperature, longitude, latitude and elevation gradients; 6) leaf hairiness would increase with reducing precipitation and aridity index and increases along temperature, longitude, latitude and elevation; and 7) significant positive relationships exist among leaf sizes, specific leaf area, petiole sizes and leaf hairiness.

\section{MATERIAL AND METHODS}

\subsection{Sample Collection and Leaf Morphological Data}

Seeds of 23 paper birch populations were collected from Newfoundland, Prince Edward Island, New Brunswick, Quebec, Ontario, Saskatchewan, and British Columbia (Figure 1). The populations' origin ranged from 20 meters to 840 meters (above sea-level) elevation, 279 $\mathrm{mm}$ to $2062 \mathrm{~mm}$ mean annual precipitation and $0.9^{\circ} \mathrm{C}$ to $8.9^{\circ} \mathrm{C}$ mean annual temperature (Table 1). Three birch seedlings from each population were grown for six months (January to June 2010) in a greenhouse at Lakehead University. We used a pre-mixed peat moss for potting medium and $21-25 \mathrm{~cm}$ (upper circle size) containers for growing. The seedlings were well watered and fertilized once a week with a regular fertilizer (N-P-K, 20:20:20). The containers were rearranged randomly on a weekly basis to minimize the effects of environmental patchiness in the greenhouse. In July 2010, we randomly harvested leaves from the middle crown of the populations. Five well-developed leaves from each seedling were randomly chosen for leaf morphological measurements and analysis.

We measured leaf size (LS), perimeter (P), blade length (BL), petiole length (PL), petiole size (PS), maximum width (MW), position of maximum width (PMW), 


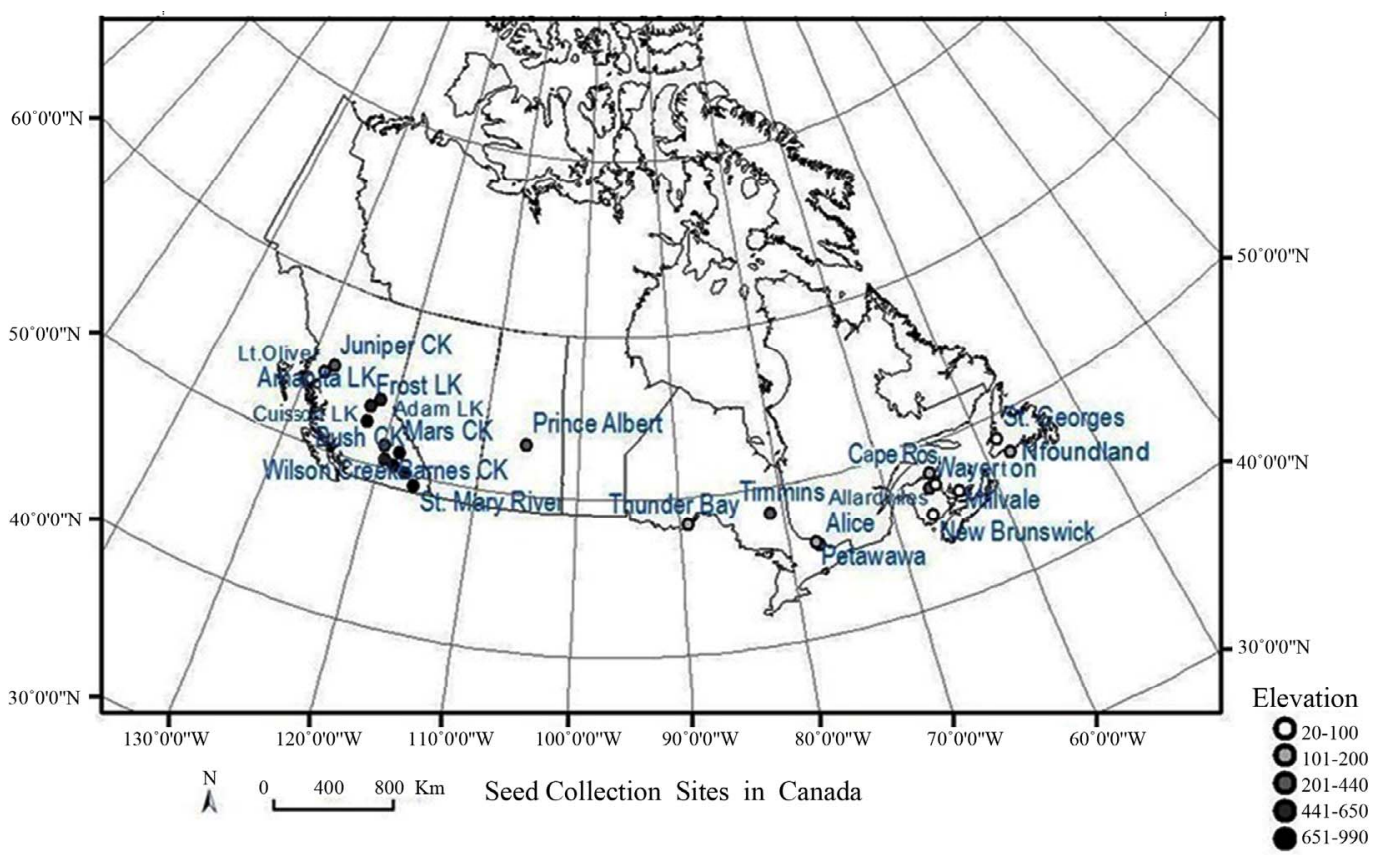

Figure 1. A map of paper birch populations originated across Canada with longitudinal and latitudinal gradient. Dot color shows elevational gradient of the population.

Table 1. Climatic data of paper birch population's origin i.e., mean annual temperature-MAT, precipitation-MAP) and aridity index — MAI, and growing season temperature - GST, precipitation — GSP and aridity index — GSA.

\begin{tabular}{|c|c|c|c|c|c|c|}
\hline Population & $\operatorname{MAT}\left({ }^{\circ} \mathrm{C}\right)$ & $\mathrm{MAP}(\mathrm{mm})$ & MAI & $\operatorname{GST}\left({ }^{\circ} \mathrm{C}\right)$ & GSP (mm) & GSA \\
\hline Newfoundland & 4.70 & 1513.70 & 102.97 & 12.00 & 100.08 & 13.50 \\
\hline St. Georges & 4.42 & 2062.60 & 143.04 & 12.93 & 110.15 & 14.26 \\
\hline Millvale & 5.23 & 1140.70 & 74.90 & 15.08 & 91.00 & 10.77 \\
\hline Allardvilles & 3.91 & 969.90 & 69.73 & 15.80 & 90.90 & 10.46 \\
\hline Cap des Rosier & 3.30 & 1128.00 & 84.81 & 13.33 & 90.78 & 11.55 \\
\hline Wayerton & 3.99 & 1032.60 & 73.81 & 15.80 & 90.90 & 10.46 \\
\hline New-Brunswick & 5.30 & 1143.30 & 74.73 & 16.25 & 90.35 & 10.21 \\
\hline Alice & 4.07 & 829.65 & 58.97 & 16.45 & 83.73 & 9.39 \\
\hline Petawawa & 4.28 & 853.30 & 59.75 & 16.18 & 76.85 & 8.71 \\
\hline Timmins & 1.36 & 831.40 & 73.19 & 14.35 & 83.03 & 10.12 \\
\hline Thunder Bay & 2.50 & 711.00 & 56.88 & 14.43 & 82.18 & 9.98 \\
\hline Prince Albert & 0.90 & 286.90 & 26.32 & 14.88 & 63.78 & 7.61 \\
\hline St. Mary River & 5.70 & 451.00 & 28.73 & 15.55 & 41.45 & 4.81 \\
\hline Wilson Creek & 7.40 & 879.00 & 50.52 & 15.85 & 38.08 & 4.37 \\
\hline Mars Creek & 4.60 & 490.70 & 33.61 & 14.88 & 42.03 & 5.01 \\
\hline Barnes Creek & 7.70 & 305.00 & 17.23 & 17.10 & 40.65 & 4.45 \\
\hline Bush Creek & 8.90 & 279.00 & 14.76 & 16.78 & 34.20 & 3.79 \\
\hline Adams Lake & 5.01 & 1076.50 & 71.72 & 13.38 & 52.33 & 6.64 \\
\hline Amanita Lake & 5.20 & 600.00 & 39.47 & 13.38 & 52.33 & 6.64 \\
\hline Cuisson Lake & 6.50 & 450.00 & 27.27 & 13.28 & 48.98 & 6.24 \\
\hline Frost Lake & 5.20 & 600.00 & 39.47 & 15.58 & 77.53 & 9.00 \\
\hline Juniper Creek & 3.90 & 613.00 & 44.10 & 12.88 & 43.23 & 5.61 \\
\hline Little-Oliver Creek & 6.30 & 1322.00 & 81.10 & 14.18 & 55.00 & 6.75 \\
\hline
\end{tabular}


horizontal width (HW) and vertical length (VL) [38-42] using WinFolia software [43]. We counted the number of hairs on three parts of each leaf surface $\left(0.20 \mathrm{~cm}^{2}\right)$ using Academic sterezoom microscope at $30 \times$ magnification and calculated average number of hairs on each adaxial and abaxial leaf surfaces for further analysis. Subsequently, sampled leaves were dried at $70^{\circ} \mathrm{C}$ for $42 \mathrm{~h}$ and leaf dry mass (DM) was measured and specific leaf area (SLA) was calculated. In addition, few leaf characteristics were calculated as ratios, since ratios relate to shape rather than size and may thus provide additional information $[6,9,29,43]$. The ratios used are:

$$
\begin{array}{r}
\text { Petiole index }(\mathrm{PI})=\mathrm{PL} / \mathrm{BL} \\
\text { Form coefficient }(\mathrm{FC})=\mathrm{P} / \mathrm{LS} \\
\text { Aspect ratio }(\mathrm{AR})=\mathrm{HW} / \mathrm{VL} \\
\text { Maximum width index }(\mathrm{MWI})=\mathrm{MW} / \mathrm{BL} \\
\text { Specific leaf area }(\mathrm{SLA})=\mathrm{LS} / \mathrm{DM}
\end{array}
$$

\subsection{Climate Data}

Mean annual and growing season temperature and precipitation data for population's origin were normalized climate data from years 1971 to 2001 [44]. We used De Martonne's equation to calculate mean annual aridity index $[45,46]$ and Sijors's equation to calculate the aridity index during the growing season [47]. The equations used are:

$$
\mathrm{MAI}=\mathrm{MAP} /(\mathrm{MAT}+10)
$$

In Eq.6, MAI is mean annual aridity index, MAP is mean annual precipitation in millimeters, and MAT is mean annual temperature in degree centigrade.

$$
\mathrm{GSA}=\left(365^{*} \mathrm{GSP}\right) /\{\mathrm{Nv}(10+\mathrm{GST})\}
$$

In Eq.7, GSA is mean aridity index during growing season, GSP is mean precipitation during growing season in millimeters, GST is mean temperature during growing season in degree centigrade and $\mathrm{Nv}$ is length of growing season in days.

\subsection{Statistical Analysis}

Assumptions of normality and homogeneity were checked for all leaf morphological characteristics with Shapiro-Wilk's Test and Levene test, respectively. Leaf characteristics like leaf size, specific leaf area, blade length, maximum width index, petiole length, petiole area, and petiole index were log transformed, and aspect ratio, form coefficient, adaxial and abaixal hairiness were square root transformed after normality testing. Analysis of variance (ANOVA) was used to analyze differences in leaf morphology of paper birch populations. We used the Tukey HSD test to analyze the morphological differences between populations.
A principal component analysis (PCA) was carried out with thirteen leaf morphological variables and these variables were reduced to five principal components that represent most of the information in the original data set. A principal component (PC) solution was determined based on the Scree plot and the Kaiser criterion (all eigenvalue greater than 1). We analyzed correlation among leaf morphological characteristics and climatic variables using Pearson's correlation. All statistical analysis was conducted using SPSS-18 (SPSS, Chicago, IL, USA) and R2.12.1 (R-Development Core team, 2011).

\section{RESULTS}

\subsection{Variations in Leaf Morphological Characteristics}

Leaf morphology differed significantly among paper birch populations grown in a greenhouse (Table 2). Leaf size, specific leaf area, petiole size, aspect ratio, form coefficient, petiole intensity and leaf hairiness varied significantly among the populations ( $\mathrm{p}<0.001$, Table 2 ). Populations from Amanita Lake and Petawawa had the smallest leaf sizes $\left(1.60 \mathrm{~cm}^{2}\right)$ that differed significantly from populations from Timmins $\left(1.81 \mathrm{~cm}^{2}\right)$, Mars Creek $\left(1.84 \mathrm{~cm}^{2}\right)$, Bush Creek $\left(1.83 \mathrm{~cm}^{2}\right)$ and Little Oliver Creek $\left(1.80 \mathrm{~cm}^{2}\right)$ (Table 3). Although, Amanita Lake population had smaller leaf size, it had significantly larger petiole area $\left(0.80 \mathrm{~cm}^{2}\right)$ and index (1.97) in comparison to the populations from Millvale $\left(0.18 \mathrm{~cm}^{2}\right.$ and $1.75 \mathrm{respec}-$ tively) and Cap des Rosier $\left(0.13 \mathrm{~cm}^{2}\right.$ and 1.78 respectively) (Table 3). Additionally, Wilson Creek and Frost Lake populations had significantly larger petiole index (1.99 and 2.00, respectively), which differed significantly from

Table 2. Analysis of variance for population effects on the leaf morphological characteristics in twenty three paper birch populations in the greenhouse. Leaf blade length, size, specific leaf area, petiole length, petiole intensity, petiole area were log transformed.

\begin{tabular}{ccc}
\hline Leaf characteristics & F-ratio $(\mathrm{df}=22)$ & P value \\
\hline Leaf size-LLS $\left(\mathrm{cm}^{2}\right)$ & 3.480 & $<0.0001$ \\
Specific leaf area-LSLA $\left(\mathrm{cm}^{2} \cdot \mathrm{g}^{-1}\right)$ & 7.757 & $<0.0001$ \\
Blade length-LBL $(\mathrm{cm})$ & 3.275 & $<0.0001$ \\
Maximum width-MW $(\mathrm{cm})$ & 5.215 & $<0.0001$ \\
Aspect ratio-SAR & 10.578 & $<0.0001$ \\
Form Coefficient-SFC & 2.665 & $<0.0001$ \\
Petiole length-LPL $(\mathrm{cm})$ & 3.904 & $<0.0001$ \\
Petiole area-LPA $\left.(\mathrm{cm})^{2}\right)$ & 8.589 & $<0.0001$ \\
Petiole intensity-LPI & 3.796 & $<0.0001$ \\
Adaxial hairiness-SADH & 7.648 & $<0.0001$ \\
Abaixal hairiness-SABH & 4.540 & $<0.0001$ \\
\hline
\end{tabular}


Table 3. Mean values with standard deviation in parenthesis of leaf morphological characteristics of paper birch populations grown in a greenhouse. Here, LLS-log leaf size, LSLA-log specific leaf area, MW-maximum width, SAR-square-root of aspect ratio, LPA-log petiole area, LPI-log petiole index and SADH- square root of numbers of hairs on adaxial surface.

\begin{tabular}{|c|c|c|c|c|c|c|c|}
\hline Populations & $\operatorname{LLS}\left(\mathrm{cm}^{2}\right)$ & $\operatorname{LSLA}\left(\mathrm{cm}^{2} / \mathrm{g}\right)$ & MW (cm) & SAR & $\operatorname{LPA}\left(\mathrm{cm}^{2}\right)$ & LPI & SADH \\
\hline Newfoundland & $1.77(0.17)$ & $2.46(0.06)$ & $8.59(1.51)$ & $0.84(0.07)$ & $0.64(0.31)$ & $1.90(0.12)$ & $2.53(0.78)$ \\
\hline St. Georges & $1.71(0.20)$ & $2.48(0.05)$ & 7.78 (1.69) & $0.78(0.05)$ & $0.43(0.32)$ & $1.88(0.12)$ & $3.07(1.06)$ \\
\hline Millvale & $1.72(0.12)$ & $2.5(0.03)$ & $7.96(1.03)$ & $0.82(0.06)$ & $0.18(0.36)$ & $1.75(0.16)$ & $2.71(0.44)$ \\
\hline Allardville & $1.71(0.14)$ & $2.48(0.03)$ & $8.04(1.33)$ & $0.83(0.06)$ & $0.32(0.49)$ & $1.78(0.16)$ & $3.09(0.97)$ \\
\hline Cap des Rosier & $1.65(0.16)$ & $2.47(0.08)$ & $7.04(1.30)$ & $0.74(0.04)$ & $0.13(0.39)$ & $1.78(0.16)$ & $3.88(0.70)$ \\
\hline Wayerton & $1.81(0.14)$ & $2.46(0.05)$ & $9.58(1.62)$ & $0.90(0.13)$ & $0.71(0.47)$ & $1.91(0.08)$ & $3.15(0.61)$ \\
\hline New Brunswick & $1.79(0.16)$ & $2.48(0.04)$ & $8.59(1.46)$ & $0.81(0.07)$ & $0.42(0.40)$ & $1.83(0.19)$ & $2.26(0.86)$ \\
\hline Alice & $1.71(0.13)$ & $2.52(0.04)$ & $7.70(0.93)$ & $0.82(0.11)$ & $0.45(0.24)$ & $1.88(0.11)$ & $2.83(0.41)$ \\
\hline Petawawa & $1.60(0.21)$ & $2.48(0.08)$ & $7.11(1.62)$ & $0.83(0.06)$ & $0.25(0.37)$ & $1.85(0.13)$ & $2.74(0.97)$ \\
\hline Timmins & $1.81(0.12)$ & $2.46(0.04)$ & $8.90(1.23)$ & $0.86(0.08)$ & $0.74(0.20)$ & $1.82(0.09)$ & $2.09(0.89)$ \\
\hline Thunder Bay & $1.73(0.13)$ & $2.52(0.06)$ & $8.20(1.28)$ & $0.81(0.08)$ & $0.44(0.44)$ & $1.91(0.14)$ & $2.06(0.44)$ \\
\hline Prince Albert & $1.74(0.17)$ & $2.51(0.03)$ & $8.46(1.71)$ & $0.82(0.03)$ & $0.34(0.45)$ & $1.82(0.19)$ & $2.54(0.66)$ \\
\hline St. Mary River & $1.77(0.10)$ & $2.54(0.04)$ & $8.81(0.83)$ & $0.92(0.09)$ & $0.79(0.39)$ & $1.89(0.17)$ & $2.24(0.53)$ \\
\hline Wilson Creek & $1.78(0.11)$ & $2.47(0.04)$ & $9.09(1.00)$ & $0.94(0.11)$ & $0.94(0.24)$ & $01.99(0.1)$ & $2.54(0.64)$ \\
\hline Mars Creek & $1.84(0.17)$ & $2.54(0.05)$ & $9.62(1.47)$ & $0.89(0.07)$ & $0.70(0.37)$ & $1.91(0.18)$ & $3.01(0.47)$ \\
\hline Barnes CK & $1.74(0.12)$ & $2.44(0.03)$ & $8.74(1.09)$ & $0.95(0.07)$ & $0.88(0.19)$ & $1.95(0.12)$ & $2.13(0.72)$ \\
\hline Bush CK & $1.83(0.15)$ & $2.50(0.04)$ & $9.81(1.43)$ & $0.91(0.05)$ & $0.80(0.39)$ & $1.93(0.16)$ & $1.58(0.64)$ \\
\hline Adams Lake & $1.78(0.18)$ & $2.45(0.05)$ & $9.32(1.48)$ & $0.92(0.08)$ & $0.84(0.34)$ & $1.90(0.16)$ & $2.05(0.88)$ \\
\hline Amanita Lake & $1.60(0.10)$ & $2.45(0.02)$ & $7.12(0.95)$ & $0.94(0.09)$ & $0.80(0.18)$ & $1.97(0.09)$ & $2.58(0.57)$ \\
\hline Cuisson Lake & $1.73(0.06)$ & $2.48(0.04)$ & $8.71(0.65)$ & $0.97(0.09)$ & $0.89(0.18)$ & $1.93(0.06)$ & $1.87(0.50)$ \\
\hline Frost Lake & $1.66(0.17)$ & $2.56(0.08)$ & $8.21(1.48)$ & $0.97(0.11)$ & $0.77(0.24)$ & $2.00(0.07)$ & $2.33(0.62)$ \\
\hline Juniper Creek & $1.67(0.14)$ & $2.52(0.04)$ & $7.91(1.41)$ & $0.89(0.11)$ & $0.52(0.50)$ & $1.89(0.18)$ & $2.30(0.51)$ \\
\hline Little Oliver Creek & $1.80(0.09)$ & $2.47(0.03)$ & $8.90(1.03)$ & $0.93(0.08)$ & $0.91(0.15)$ & $1.91(0.11)$ & $2.74(0.33)$ \\
\hline
\end{tabular}

those of Allardville (1.78), Cap des Rosier (1.78), Millvale (1.75), New Brunswick (1.90) and Timmins (1.82) (Table 3).

Specific leaf area was the highest in Frost Lake (2.56 $\left.\mathrm{cm}^{2} \cdot \mathrm{g}^{-1}\right)$ and the lowest in Barnes Creek $\left(2.44 \mathrm{~cm}^{2} \cdot \mathrm{g}^{-1}\right)$ (Table 3). Population from Barnes Creek significantly differed from Frost Lake $\left(2.56 \mathrm{~cm}^{2} \cdot \mathrm{g}^{-1}\right)$, Mars Creek (2.54 $\left.\mathrm{cm}^{2} \cdot \mathrm{g}^{-1}\right)$, and St. Mary River $\left(2.54 \mathrm{~cm}^{2} \cdot \mathrm{g}^{-1}\right)$ populations (Table 3). Furthermore, the populations from Frost Lake, Mars Creek and St. Mary River differed significantly from Adams Lake $\left(2.45 \mathrm{~cm}^{2} \cdot \mathrm{g}^{-1}\right)$, Amanita Lake $(2.45$ $\mathrm{cm}^{2} \cdot \mathrm{g}^{-1}$ ), Barnes Creek $\left(2.44 \mathrm{~cm}^{2} \cdot \mathrm{g}^{-1}\right)$, Cap des Rosier $\left(2.47 \mathrm{~cm}^{2} \cdot \mathrm{g}^{-1}\right)$, Little Oliver Creek $\left(2.47 \mathrm{~cm}^{2} \cdot \mathrm{g}^{-1}\right)$, New Brunswick $\left(2.48 \mathrm{~cm}^{2} \cdot \mathrm{g}^{-1}\right)$, Newfoundland $\left(2.46 \mathrm{~cm}^{2} \cdot \mathrm{g}^{-1}\right)$, Timmins $\left(2.46 \mathrm{~cm}^{2} \cdot \mathrm{g}^{-1}\right)$ and Wayerton $\left(2.46 \mathrm{~cm}^{2} \cdot \mathrm{g}^{-1}\right)$, all which had smaller specific leaf areas (Table 3).
Leaf hairiness on adaxial surface ranged from 1.58 in Cuisson Lake to 3.88 in Cap des Rosier and abaixal surface from 3.05 in Cuisson Lake to 4.64 in Allardville (Table 3). The population from Cuisson Lake with the lowest number of hairs (adaxial and abaixal) differed from populations from Alice (2.83 and 4.46), Allardville (30.9 and 4.64), Little Oliver Creek (2.74 and 4.50), Mars Creek (3.01 and 4.40), Millvale (2.71 and 4.48), New Brunswick (2.26 and 4.18), Petawawa (2.74 and 4.50), Prince Albert (2.54 and 4.37), St. Mary River (2.24 and 4.29) and Wayerton (3.15 and 4.57) (Table 3). On the other hand, Cap des Rosier population did not differ significantly from Allardvilles, Mars Creek, St. Georges and Wayerton, with respect to leaf hairiness on adaxial surfaces (Table 3). Furthermore, Cap des Rosier had the narrowest leaf $(7.04 \mathrm{~cm})$ with least maximum width index 
(1.84) whereas Bush Creek had the widest leaf $(9.81 \mathrm{~cm})$ and width index (1.96) (Table 3). The population from Cap des Rosier had significantly narrower leaf and width index than the populations from Adams Lake $(9.32 \mathrm{~cm}$ and 1.94), Bush Creek (9.81 cm and 1.96), Little Oliver Creek (8.90 cm and 1.89), Mars Creek (9.62 cm and 1.92), Newfoundland $(8.59 \mathrm{~cm}$ and 1.87$)$, Wayeryon $(9.58 \mathrm{~cm}$ and 1.93) and Wilson Creek (9.09 cm and 1.94) (Table 3).

On the other hand, Bush Creek had significantly wider leaf and width index compared to the populations from Alice $(7.70 \mathrm{~cm}$ and 1.85), Amanita Lake $(9.32 \mathrm{~cm}$ and 1.94), Cap des Rosier (7.04 cm and 1.84), Millvale (7.96 $\mathrm{cm}$ and 1.87), Petawawa (7.11 cm and 1.89) and St. Georges $(7.78 \mathrm{~cm}$ and 1.85$)\left(\mathrm{cm}^{2} \cdot \mathrm{g}^{-1}\right)$.

\subsection{Relationship between Leaf Morphology and Climate of a Population's Origin}

The PCA resolved five principal components (PC) explaining $84.74 \%$ of the total variance in the data (Table 4).

Table 4. Principal component analysis for leaf characteristics for paper birch populations grown in a greenhouse. Measured leaf characteristics were: SDW - square root leaf dry weight, LLS - log leaf size $\left(\mathrm{cm}^{2}\right)$, LSA - log specific leaf area $\left(\mathrm{cm}^{2} / \mathrm{g}\right)$, PER-perimeter $(\mathrm{cm})$, MW-leaf maximum width $(\mathrm{cm})$, LMWI- $\log$ maximum width index, SAR - square-root of aspect ratio (horizontal width/vertical length of leaf), SFC square-root of form coefficient (perimeter/area), LPL- $\log$ petiole length $(\mathrm{cm})$, LPA- $\log$ petiole area $\left(\mathrm{cm}^{2}\right)$, LPI-log petiole index and SADH-square-root of number of hairs on leaf adaxial surface and $\mathrm{SABH}$ - square-root of number of hairs on leaf abaixal surface. Variables with high loadings on each of the principal components are indicated boldfaced.

\begin{tabular}{ccccccc}
\hline & PC1 & PC2 & PC3 & PC4 & PC5 & \\
\hline Eigen values & 4.20 & 3.05 & 1.62 & 1.12 & 1.03 & \\
Variance \% & 32.31 & 23.44 & 12.46 & 8.64 & 7.89 & \\
Cumulative \% & 32.31 & 55.76 & 68.22 & 76.85 & 84.74 & \\
Leaf characteristics & & Eigenvectors & Communality \\
SDW & 0.90 & -0.27 & -0.08 & -0.27 & -0.17 & 0.99 \\
LLA & 0.91 & -0.36 & -0.04 & -0.02 & 0.04 & 0.96 \\
LSLA & -0.01 & -0.27 & 0.09 & 0.72 & 0.57 & 0.92 \\
PER & 0.87 & -0.43 & 0.16 & 0.09 & 0.04 & 0.97 \\
MW & 0.95 & -0.14 & 0.02 & 0.11 & -0.06 & 0.94 \\
LMWI & 0.07 & 0.60 & 0.16 & 0.43 & -0.35 & 0.70 \\
SAR & 0.22 & 0.69 & 0.26 & 0.25 & -0.40 & 0.81 \\
SFC & -0.16 & 0.27 & -0.49 & -0.26 & 0.02 & 0.40 \\
LPL & 0.59 & 0.62 & -0.02 & -0.19 & 0.46 & 0.98 \\
LPA & 0.62 & 0.68 & 0.14 & -0.06 & 0.03 & 0.87 \\
LPI & 0.09 & 0.89 & 0.02 & -0.10 & 0.37 & 0.95 \\
SADH & -0.28 & -0.13 & 0.70 & -0.37 & 0.20 & 0.76 \\
SABH & -0.09 & -0.10 & 0.86 & -0.12 & -0.05 & 0.77 \\
\hline
\end{tabular}

Communality values were greater than 0.70 for all leaf characteristics except for form coefficient $(0.40)$. The eigenvectors value in $\mathrm{PC} 1$ was positively related to leaf dry weight, size, perimeter, and maximum width. PC2 was strongly related to leaf maximum width index, aspect ratio, petiole length, petiole area and petiole index. PC3 was negatively related to form coefficient and positively related to hairiness of leaf on adaxial and abaixal surfaces. PC4 was related to specific leaf area and maximum width index. Lastly, PC5 was related to specific leaf area, form coefficient and petiole length (Table 4). The correlation result indicated that leaf morphological characteristics exhibited consistent multivariate patterns related to environmental variables of population's origin (Table 5).

Correlation analysis revealed that the scores of PC2 and PC4 were positively related to latitude $(r=0.31$ and $r$ $=0.36, \mathrm{p}<0.001$ respectively), longitude $(\mathrm{r}=0.34$ and $\mathrm{r}$ $=0.46, \mathrm{p}<0.001$ respectively) (Figure 2(a)) and elevation $(\mathrm{r}=0.35$ and $\mathrm{r}=0.42, \mathrm{p}<0.001$ respectively) (Figure 2(b), Table 5). Along climatic gradient, both PC2 and

Table 5. Pearson correlation between five principal components and geography and climate of population's origin of paper birch populations. Here, MAT is mean annual temperature in ${ }^{\circ} \mathrm{C}$, MAP is mean annual precipitation in millimeters, MAI is mean annual aridity index, GST is growing season temperature in ${ }^{\circ} \mathrm{C}$, GSP is growing season precipitation in millimeters and GSA is growing season aridity index. Values are correlation coefficient ( $\mathrm{r}$ ) with $\mathrm{p}$ values in parenthesis.

\begin{tabular}{|c|c|c|c|c|c|}
\hline $\begin{array}{c}\text { Environment } \\
\text { of origin }\end{array}$ & $\mathrm{PC} 1$ & PC2 & PC3 & PC4 & PC5 \\
\hline \multirow{2}{*}{ Latitude } & 0.07 & 0.31 & 0.12 & 0.36 & -0.09 \\
\hline & $(0.16)$ & $(<0.001)$ & $(0.01)$ & $(<0.001)$ & $(0.06)$ \\
\hline \multirow{2}{*}{ Longitude } & 0.13 & 0.34 & 0.14 & 0.46 & -0.11 \\
\hline & $(0.01)$ & $(<0.001)$ & $(<0.001)$ & $(<0.001)$ & $(0.02)$ \\
\hline \multirow{2}{*}{ Elevation } & 0.17 & 0.35 & 0.13 & 0.42 & -0.08 \\
\hline & $(<0.001)$ & $(<0.001)$ & $(0.01)$ & $(<0.001)$ & $(0.09)$ \\
\hline \multirow{2}{*}{ MAT } & 0.15 & 0.27 & 0.02 & 0.17 & -0.11 \\
\hline & $(<0.001)$ & $(<0.001)$ & $(0.62)$ & $(<0.001)$ & $(0.02)$ \\
\hline \multirow{2}{*}{ MAP } & -0.05 & -0.18 & -0.14 & -0.46 & 0.10 \\
\hline & $(0.34)$ & $(<0.001)$ & $(<0.001)$ & $(<0.001)$ & $(0.03)$ \\
\hline \multirow{2}{*}{ MAI } & -0.06 & -0.22 & -0.15 & -0.49 & 0.11 \\
\hline & $(0.18)$ & $(<0.001)$ & $(<0.001)$ & $(<0.001)$ & $(0.02)$ \\
\hline \multirow[t]{2}{*}{ GST } & 0.03 & -0.01 & 0.15 & 0.21 & -0.02 \\
\hline & $(0.59)$ & $(0.82)$ & $(<0.001)$ & $(<0.001)$ & $(0.70)$ \\
\hline \multirow[t]{2}{*}{ GSP } & -0.15 & -0.30 & -0.15 & -0.43 & 0.17 \\
\hline & $(<0.001)$ & $(<0.001)$ & $(<0.001)$ & $(<0.001)$ & $(<0.001)$ \\
\hline \multirow{2}{*}{ GSA } & -0.14 & -0.27 & -0.17 & -0.44 & 0.16 \\
\hline & $(<0.001)$ & $(<0.001)$ & $(<0.001)$ & $(<0.001)$ & $(<0.001)$ \\
\hline
\end{tabular}




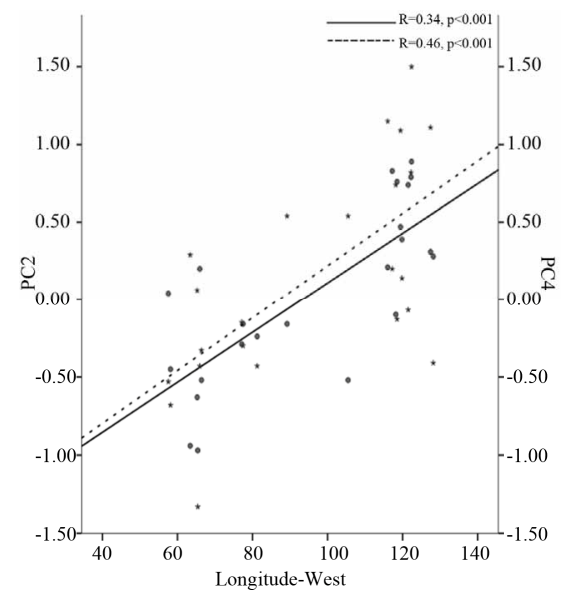

(a)

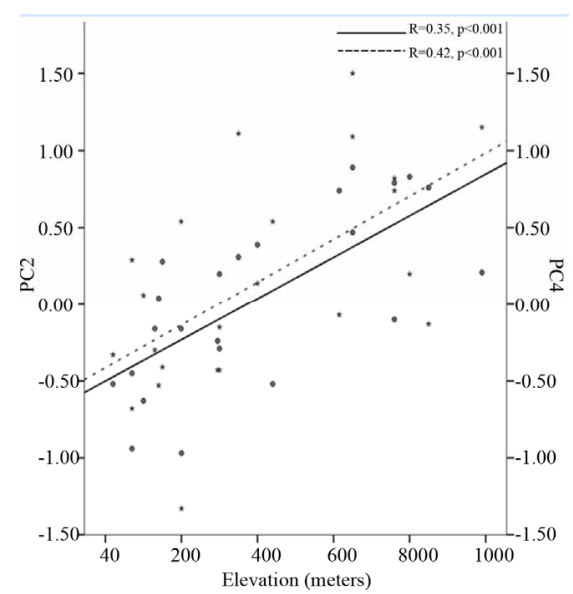

(b)

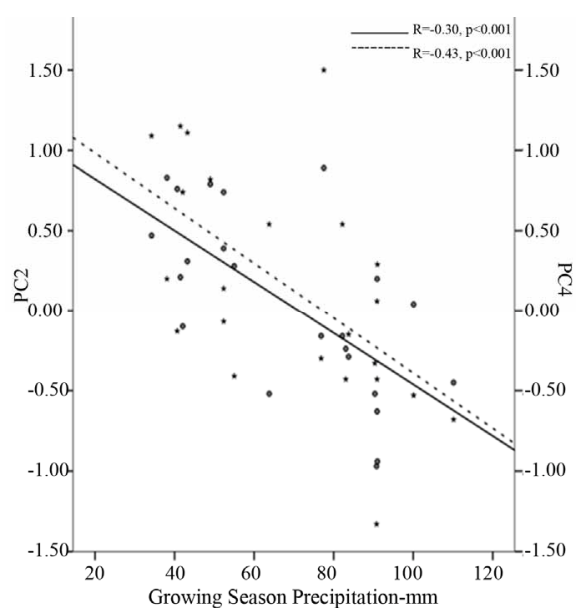

(c)

Figure 2. Correlation of the second principal component (PC2) and the fourth principal component (PC) to longitude-west (a), elevation-meters (b) and growing season precipitation-mm (c). PC2 is accumulated with petiole length, petiole size, petiole index, leaf maximum width index and aspect ratio while PC4 is accumulated with specific leaf area and leaf maximum width index.
PC4 were significantly positively correlated to mean annual temperature $(\mathrm{r}=0.27$ and $\mathrm{r}=0.17, \mathrm{p}<0.001$ respectively), however, negatively related to precipitation ( $\mathrm{r}=$ -0.18 and $\mathrm{r}=-0.46, \mathrm{p}<0.001$ respectively) and aridity index $(\mathrm{r}=-0.22$, and $\mathrm{r}=-0.49, \mathrm{p}<0.001$ respectively) (Table 5). Furthermore, analysis of morphological variables against climate during growing season indicated that the scores of PC2 and PC4 were strongly correlated to precipitation $(\mathrm{r}=-0.30$ and $\mathrm{r}=-0.43, \mathrm{p}<0.001 \mathrm{re}-$ spectively) (Figure 2(c)) and aridity $(\mathrm{r}=-0.27$ and $\mathrm{r}=$ $-0.44, \mathrm{p}<0.001$ respectively) (Table 5 ). There was significant correlation between PC4 and temperature during growing season $(\mathrm{r}=0.21, \mathrm{p}<0.001)$. On the contrary, PC1, PC3 and PC5 were not strongly correlated to the environmental variables measured (Table 5).

\subsection{Relationships among Leaf Morphological Characteristics and to Growing Season Climate of a Population's Origin}

Among leaf morphological characteristics, petiole size significantly increased in larger leaves $(r=0.31, p<$ $0.001)$ with increased maximum width $(\mathrm{r}=0.47, \mathrm{p}<$ $0.001)$, maximum width index $(\mathrm{r}=0.42, \mathrm{p}<0.001)$ and aspect ratio $(\mathrm{r}=0.66, \mathrm{p}<0.001)$ (Table 6). Increase in the maximum width index had significantly increased petiole index $(r=0.42, p<0.001)$ (Figure 3$)$. Although the correlation was not as strong as in petiole size, specific leaf area (SLA) was significantly larger in elongated leaves $(r$ $=-0.17, \mathrm{p}<0.001)$ with smaller petiole area $(\mathrm{r}=-0.18, \mathrm{p}$ $<0.001)$ and petiole index $(\mathrm{r}=-0.15, \mathrm{p}<0.001)$ (Table 6). In the same way, leaf hairiness on the adaxial surface was more in smaller leaf size $(r=-0.18 p<0.001)$, maxi-

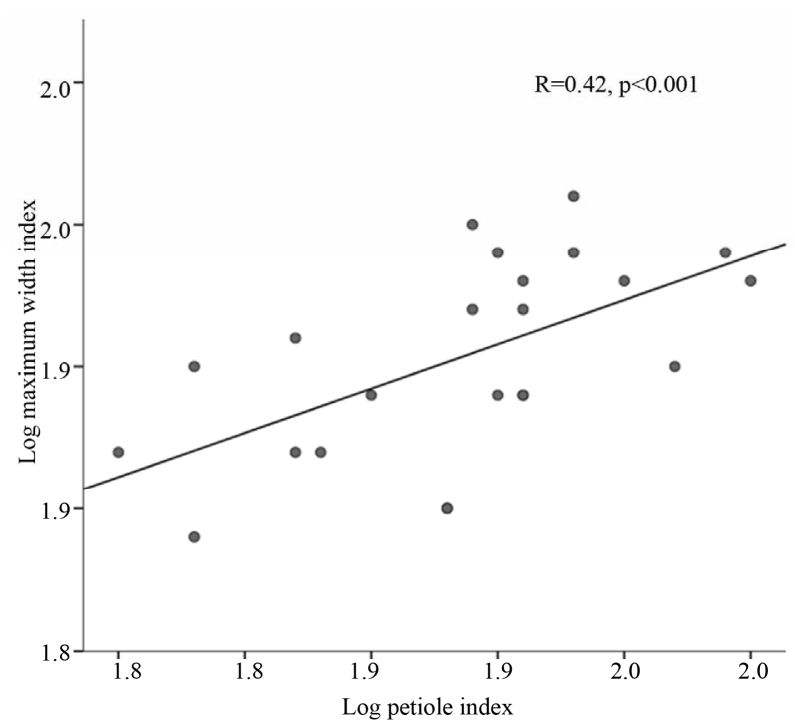

Figure 3. Correlation between leaf maximum width index $(\log )$ and petiole index $(\log )$ in paper birch populations growing in greenhouse. 
Table 6. Pearson correlation among leaf characteristics and growing season climate of paper birch populations grown in a greenhouse. Measured leaf characteristics were: LLS - log leaf size $\left(\mathrm{cm}^{2}\right)$, LSA- $\log$ specific leaf area $\left(\mathrm{cm}^{2} / \mathrm{g}\right), \mathrm{MW}$ - leaf maximum width $(\mathrm{cm})$, LMWI - log maximum width index, SFC — square-root of form coefficient, LPA — log petiole area $\left(\mathrm{cm}^{2}\right)$, LPI- $\log$ petiole index and SADH and SABH - square-root of number of hairs on leaf adaxial and abaixal surfaces respectively. GST $\left({ }^{\circ} \mathrm{C}\right)$, GSP (mm) and GSA are growing season temperature, precipitation and aridity index respectively. Values area correlation coefficient (r) with $\mathrm{p}$ values.

\begin{tabular}{|c|c|c|c|c|c|c|c|c|c|c|}
\hline & LLA & LSLA & MW & LMWI & SFC & LPL & LPA & LPI & SADH & $\mathrm{SABH}$ \\
\hline \multirow{2}{*}{ LSLA } & 0.14 & & & & & & & & & \\
\hline & $(<0.001)$ & & & & & & & & & \\
\hline \multirow{2}{*}{ MW } & 0.94 & 0.11 & & & & & & & & \\
\hline & $(<0.001)$ & $(0.02)$ & & & & & & & & \\
\hline \multirow{2}{*}{ LMWI } & -0.13 & -0.02 & 0.15 & & & & & & & \\
\hline & $(0.01)$ & $(0.60)$ & $(<0.001)$ & & & & & & & \\
\hline \multirow{2}{*}{ SFC } & -0.09 & -0.09 & -0.09 & 0.12 & & & & & & \\
\hline & $(0.05)$ & $(0.07)$ & $(0.06)$ & $(0.01)$ & & & & & & \\
\hline \multirow{2}{*}{ LPL } & 0.33 & -0.09 & 0.41 & 0.16 & 0.07 & & & & & \\
\hline & $(<0.001)$ & $(0.07)$ & $(<0.001)$ & $(<0.001)$ & $(0.14)$ & & & & & \\
\hline \multirow{2}{*}{ LPA } & 0.31 & -0.18 & 0.47 & 0.34 & 0.01 & 0.77 & & & & \\
\hline & $(<0.001)$ & $(<0.001)$ & $(<0.001)$ & $(<0.001)$ & $(0.77)$ & $(<0.001)$ & & & & \\
\hline \multirow{2}{*}{ LPI } & -0.24 & -0.15 & -0.08 & 0.42 & 0.16 & 0.82 & 0.63 & & & \\
\hline & $(<0.001)$ & $(<0.001)$ & $(0.07)$ & $(<0.001)$ & $(<0.001)$ & $(<0.001)$ & $(<0.001)$ & & & \\
\hline \multirow{2}{*}{ SADH } & -0.18 & 0.01 & -0.22 & -0.09 & -0.08 & -0.15 & -0.15 & -0.06 & & \\
\hline & $(<0.001)$ & $(0.80)$ & $(<0.001)$ & $(0.05)$ & $(0.08)$ & $(<0.001)$ & $(<0.001)$ & $(0.22)$ & & \\
\hline \multirow{2}{*}{$\mathrm{SABH}$} & -0.04 & 0.04 & -0.04 & 0.05 & -0.21 & -0.13 & -0.02 & -0.09 & 0.54 & \\
\hline & $(0.39)$ & $(0.36)$ & $(0.45)$ & $(0.29)$ & $(<0.001)$ & $(0.01)$ & $(0.65)$ & $(0.06)$ & $(<0.001)$ & \\
\hline \multirow{2}{*}{ GSP } & -0.02 & -0.13 & -0.15 & -0.45 & 0.16 & -0.12 & -0.30 & -0.19 & 0.20 & -0.05 \\
\hline & $(0.75)$ & $(0.01)$ & $(<0.001)$ & $(<0.001)$ & $(<0.001)$ & $(0.01)$ & $(<0.001)$ & $(<0.001)$ & $(<0.001)$ & $(0.28)$ \\
\hline \multirow{2}{*}{ GST } & 0.04 & 0.17 & 0.07 & 0.10 & -0.05 & -0.02 & -0.04 & -0.02 & -0.08 & 0.25 \\
\hline & $(0.46)$ & $(<0.001)$ & $(0.17)$ & $(0.04)$ & $(0.29)$ & $(0.72)$ & $(0.43)$ & $(0.66)$ & $(0.10)$ & $(<0.001)$ \\
\hline \multirow{2}{*}{ GSA } & -0.01 & -0.16 & -0.14 & -0.42 & 0.16 & -0.09 & -0.26 & -0.16 & 0.20 & -0.11 \\
\hline & $(0.77)$ & $(<0.001)$ & $(<0.001)$ & $(<0.001)$ & $(<0.001)$ & $(0.05)$ & $(<0.001)$ & $(<0.001)$ & $(<0.001)$ & $(0.02)$ \\
\hline
\end{tabular}

mum width $(\mathrm{r}=-0.22, \mathrm{p}<0.001)$ (Table 6) and petiolesize $(r=-0.15 p<0.001)$ (Table 6). A correlation between form coefficient and leaf hairs on abaixal surfaces $(\mathrm{r}=-0.21, \mathrm{p} \leq 0.001)$ indicated that rounded leaves had more hairs on abaixal surface.

Comparing each leaf morphological characteristics and growing season climate of population's origin, the results showed that leaf maximum width index and petiole area significantly decreased along precipitation and aridity index gradients (Table 6). On the other hand, leaf adaxial hairs increased with increasing precipitation and aridity index $(r=0.20$ and $r=0.20,<0.001$ respectively) (Table 6). There was no significant relationship between leaf characteristics and temperature except for leaf abaixal hairs, which increased along temperature gradient $(\mathrm{r}=$ $0.25, \mathrm{p}<0.001$ ) (Table 6). Similar to the results of multivariate patterns, there was no significantly relationship between leaf sizes and climate.

\section{DISCUSSION}

As hypothesized, we found that leaf morphological characteristics of paper birch vary among populations grown under uniform conditions in a greenhouse. The morphological variations may be related to genotypic difference of paper birch populations originated in wide 
environmental gradient. Our results were consistent to studies on Azadirachta indica [8], Eucalyptus sideroxylon [9], Nothofagus cunninghamii [48], Quercus petraea [28], and Parkia biglobosa [49]. Additionally, the environmental differences at population's origin identified among genotypes in this study and others studies $[8,9,50]$ likely had contributed to the leaf variations in the birch populations.

In our second hypothesis, we tested if genotypic difference in the leaf morphological characteristics were related to the environment of the birch population's origin. The results showed that leaf characteristics such as specific leaf area, leaf maximum width index, petiole size, petiole index and aspect ratio were significantly related to environmental variables at a population's origin. The prevailing view is that low specific leaf area work better in resource poor environments where retaining captured resources is essential [51]. Similarly, a narrow leaf with smaller petiole size are viewed as an adaptation to sunny and dry environments for controlling water balance [52-54]. However, contrary to our hypothesis, the present results showed that SLA, leaf maximum width, aspect ratio and petiole sizes increased in warmer and drier region along longitude, latitude and elevational gradients. A combination of wide leaves and high SLA has been commonly reported in fast growing species [53] but this multivariate trait often showed inconsistent to environmental gradients $[6,9,55]$. Hence, it was argued that leaf life span, root structure, water use efficiency, growth stage and nutrient availability also influence SLA and leaf width $[9,56,57]$. In consistent to our results, petiole length increased with increasing drought in deciduous trees [27]. Thus, increased petiole length and leaf width, in our study, is probably to promote leaf cooling in drier regions. Another possible explanation for these contrasting results in our study is that in the greenhouse seedlings were watered regularly, thus, populations originated in drier and warmer habitats were experiencing more than adequate environmental conditions whereas populations from wetter habitats were experiencing comparatively stressed environment [58,59]. Thus, we concluded that the plasticity of the birch might have resulted contrary leaf characteristics in the greenhouse plants.

Many species generally reduce leaf size [8] and/or increase in leaf hairiness [60] under water deficiency or increased temperature. However, our PCA result did not support our hypotheses; the result was consistent with a study on the southern beech [48] and Eucalyptus sideroxylon [9] that had either insignificant or weak relation between leaf characteristics and environmental variables. Previous studies suggested that plants develop traits that either diminishes the loss of water or reduces the need for water by increasing water use efficiency [27,61] under environmental stress. The modifications are basically in leaf sizes, hairiness, and petiole size.

Small leaves with hairs could reduce transpiration by lowering leaf temperature or by changing boundary layer conditions [62,63]. Thus, we assumed that correlations among leaf characters might have supported the birch populations to produce leaf characterizes other than what we hypothesized. Supporting our last hypothesis, we found significant correlations among leaf characteristics; populations with larger and wider leaf had larger petiole and fewer adaxial hairs. The larger petiole reflects the need for mechanical strengthening to support large leaves [24-26]. Furthermore, smaller and hairy leaves have reduced surface area which could reduce transpiration by lowering leaf temperature or by changing boundary layer conditions $[63,64]$.

Given that small, hairy leaves tend to reduce water loss, we expected that smaller, narrower and hairier leaves in hot and dry environments. In this study, paper birch had more abaxial and adaxial hairs in hot and dry regions respectively. In consistent to previous studies [60, 65], an increase in leaf abaxial hairs might be a strategy of the birch to reduce water loss. In contrary to expectations, leaf hairs on adaxial surfaces were more in paper birch originated in wetter regions. However, the inverse relation between the adaxial hairiness and leaf width found in this study shows a possible tradeoff between these leaf characteristics to balance evaporation rate in wetter regions.

In conclusion, our results raise the possibility that intraspecific variation in paper birch might evolve due to genotypic variation and environmentally induced variation in leaf morphological characteristics. Contrary to our expectations, several leaf characteristics were inversely related to environmental gradient of the birch's origin. We should consider the fact that the greenhouse had different environment than the habitat the populations would normally be exposed to. Thus, phenotypic plasticity of the birch possibly has imposed leaf characteristics contrary to our expectations [66]. Furthermore, the tradeoff between leaf characteristics in this study might have enhanced water use strategy in extreme environments.

\section{ACKNOWLEDGEMENTS}

The research was founded by NSERC discovery grant to JW. We appreciate that Joan Lee, Lakehead University greenhouse manager, provided all logistic support for the greenhouse experiment. We also thank Prof. Dr. Albert Reif and Samuel F. Bartels for their feedbacks.

\section{REFERENCES}

[1] Via, S. and Lande, R. (1985) Genotype-environment interaction and the evolution of phenotypic plasticity. Evolution, 39, 505-522. doi:10.2307/2408649 
[2] Jonas, C.S. and Geber, M.A. (1999) Variation among populations of Clarkia unguiculata (Onagraceae) along altitudinal and latitudinal gradients. American Journal of Botany, 86, 333-343. doi:10.2307/2656755

[3] Bloom, A.J., Chapin, F.S. and Mooney, H.A. (1985) Resource limitation in plants-An economic analogy. Annual Review of Ecology and Systematics, 16, 363-392. doi:10.1146/annurev.ecolsys.16.1.363

[4] McLellan, T. (2000) Geographic variation and plasticity of leaf shape and size in Begonia dregei and B. homonyma (Begoniaceae). Botanical Journal of the Linnean Society, 132, 79-95. doi:10.1006/bojl.1999.0292

[5] Ohsawa, T. and Ide, Y. (2008) Global patterns of genetic variation in plant species along vertical and horizontal gradients on mountains. Global Ecology and Biogeography, 17, 152-163. doi:10.1111/j.1466-8238.2007.00357

[6] Uribe-Salas, D., Sáenz., R.C., González, R.A., Téllez, V.O. and Oyama, K. (2008) Foliar morphological variation in the white oak Quercus rugosa Née (Fagaceae) along a latitudinal gradient in Mexico: Potential implications for management and conservation. Forest Ecology and Management, 256, 2121-2126. doi:10.1016/j.foreco.2008.08.002

[7] Coleman, J.S., McConnaughay, K.D.M. and Ackerly, D.D. (1994) Interpreting phenotypic variation in plants. Trends in Ecology \& Evolution (Personal Edition), 9, 187-191. doi:10.1016/0169-5347(94)90087-6

[8] Kundu, S.K. and Tigerstedt, P.M.A. (1997) Geographical variation in seed and seedling traits of Neem (Azadirachta indica A. JUSS.) among ten populations studied in growth chamber. Silvae Genetica, 46, 2-3.

[9] Warren, C.R., Tausz, M. and Adams, M.A. (2005) Does rainfall explain variation in leaf morphology and phy- siology among populations of red ironbark (Eucalyptus sideroxylon subsp. tricarpa) grown in a common garden? Tree Physiology, 25, 1369-1378. doi:10.1093/treephys/25.11.1369

[10] Gates, D.M., Alderfer, R. and Taylor, E. (1968) Leaf temperatures of desert plants. Science, 159 994-995. doi:10.1126/science.159.3818.994

[11] Cordell, S., Goldstein, G., Mueller-Dombois, D., Webb, D. and Vitousek, P.M. (1998) Physiological and morphological variation in Metrosideros polymorpha, a dominant Hawaiian tree species, along an altitudinal gradient: The role of phenotypic plasticity. Oecologia, 113, 188-196. doi:10.1007/s004420050367

[12] McDonald, P.G., Fonseca, C.R., Overton, J.M. and Westoby, M. (2003) Leaf-size divergence along rainfall and soil-nutrient gradients: Is the method of size reduction common among clades? Functional Ecology, 17, 50-57. doi:10.1046/j.1365-2435.2003.00698.x

[13] Roderick, M.L., Berry, S.L., and Noble, I.R. (2000) A framework for understanding the relationship between environment and vegetation based on the surface area to volume ratio of leaves. Functional Ecology, 14, 423-437. doi:10.1046/j.1365-2435.2000.00438.x

[14] Milla, R. and Reich, P.B. (2007) The scaling of leaf area and mass: The cost of light interception increases with leaf size. Proceedings of the Royal Society B: Biological
Sciences, 274, 2109-2115. doi:10.1098/rspb.2007.2003

[15] Donselman, H.M. and Flint, H.L. (1982) Genecology of eastern redbud (Cercis canadensis). Ecology, 63, 962-971. doi: $10.2307 / 1937236$

[16] Hilaire, R.S. and Graves, W.R. (1999) Foliar traits of sugar maples and black maples near $43^{\circ} \mathrm{N}$ latitude in the eastern and central United States. Journal of the American Society for Horticultural Science, 124, 605-611.

[17] Ehleringer, J.R. and Mooney, H.A. (1978) Leaf hairs: Effects on physiological activity and adaptive value to a desert shrub. Oecologia, 37, 183-200. doi:10.1007/BF00344990

[18] Ehleringer, J., Mooney, H.A., Gulmon, S.L. and Rundel, P.W. (1981) Parallel evolution of leaf pubescence in encelia in coastal deserts of North and South America. Oecologia, 49, 38-41. doi:10.1007/BF00376895

[19] Ehleringer, J.R. and Björkman, O. (1978) Pubescence and leaf spectral characteristics in a desert shrub, Encelia farinosa. Oecologia, 36, 151-162. doi:10.1007/BF00349805

[20] Picotte, J.J., Rosenthal, D.M., Rhode, J.M. and Cruzan, M.B. (2007) Plastic responses to temporal variation in moisture availability: Consequences for water use efficiency and plant performance. Oecologia, 153, 821-832.

[21] Abrams, M.D. (1990) Adaptations and responses to drought in Quercus species of North America. Tree Physiology, 7, 227-238. doi:10.1093/treephys/7.1-2-3-4.227

[22] Abrams, M.D. (1994) Genotypic and phenotypic variation as stress adaptations in temperate tree species: A review of several case studies. Tree Physiology, 14, 833842. doi:10.1093/treephys/14.7-8-9.833

[23] Werger, M.J.A. and Ellenbroek, G.A. (1978) Leaf size and leaf consistence of a riverine forest formation along a climatic gradient. Oecologia, 34, 297-308. doi:10.1007/BF00344908

[24] Niinemets, U., Afas, N.A., Cescatti, A., Pellis, A. and Ceulmans, R. (2004) Petiole length and biomass investment in support modify light interception efficiency in dense poplar plantations. Tree Physiology, 24, 141-154. doi:10.1093/treephys/24.2.141

[25] Niinemets, U., Portsmuth, A. and Tobias, M. (2006) Leaf size modifies support biomass distribution among stems, petioles and mid-ribs in temperate plants. New Phytologist, 171, 91-104.

[26] Poorter, L. and Rozendaal, D.M. (2008) Leaf size and leaf display of thirty-eight tropical tree species. Oecologia, 158, 35-46. doi:10.1007/s00442-008-1131-x

[27] Meng, T.T., Ni, J. and Harrison, S.P. (2009) Plant morphometric traits and climate gradients in northern China: A meta-analysis using quadrat and flora data. Annals of Botany, 104, 1217-1229. doi:10.1093/aob/mcp230

[28] Bruschi, P., Grossoni, P. and Bussotti, F. (2003) Withinand among-tree variation in leaf morphology of Quercus petraea (Matt.) Liebl. natural populations. Trees, 17, 164 172.

[29] Calagari, M., Modirrahmati, A.R. and Asadi, F. (2006) Morphological variation in leaf traits of Populus euphratica Oliv. natural populations. International Journal 
of Agriculture \& Biology, 8, 754-758.

[30] Joel, G., Aplet, G. and Vitousek, P.M. (1994) Leaf morphology along environmental gradients in Hawaiian Metrosideros polymorpha. Biotropica, 26, 17-22. doi:10.2307/2389106

[31] Aspelmeier, S. and Leuschner, C. (2006) Genotypic variation in drought response of silver birch (Betula pendula Roth): Leaf and root morphology and carbon partitioning. Trees, 20, 42-52. doi:10.1007/s00468-005-0011-9

[32] Dancik, B.P. and Barnes, B.V. (1974) Leaf diversity in yellow birch (Betula alleghaniensis). Canadian Journal of Botany, 52, 2407-2414. doi:10.1139/b74-312

[33] Senn, J., Hanhimäki, S. and Haukioja, E. (1992) Among tree variation in leaf phenology and morphology and its correlation with insect performance in the mountain birch. Oikos, 63, 215-222. doi:10.2307/3545381

[34] Sharik, T.L. and Barnes, B.V. (1979) Natural variation in morphology among diverse populations of yellow birch (Betula alleghaniensis) and sweet birch (B. lenta). Canadian Journal of Botany, 57, 1932-1939. doi:10.1139/b79-242

[35] Ashton, P.M.S., Plander, L.P., Berlyn, P., Thadani, R. and Cameron, I.R. (1998) Changes in leaf structure in relation to crown position and tree size of Betula papyrifera within fire-origin stands of interior cedar-hemlock. Canadian Journal of Botany, 76, 1180-1187. doi:10.1139/cjb-76-7-1180

[36] Farrar, J.L. (1995) Trees in Canada. Fitzhenry \& Whiteside Limited, Markham.

[37] Gurevitch, J. (1992) Sources of variation in leaf shape among two populations of Achillea lanulosa. Genetics, 130, 385-394.

[38] Aas, G. (1993) Taxonomical impact of morphological variation in Quercus robur and Q. petraea: A contribution to the hybrid controversy. Annals of Forest Sciences, 50, 107-113. doi:10.1051/forest:19930709

[39] Bruschi, P., Vendramin, G.G., Bussotti, F.A. and Grossoni, P. (2000) Morphological and molecular differentiation between Quercus petraea (Matt.) liebl. and Quercus pubescens willd. (Fagaceae) in Northern and Central Italy. Annals of Botany, 85, 325-333. doi:10.1006/anbo.1999.1046

[40] Curtu, A.L., Gailing, O., Leinemann, L. and Finkeldey, R. (2007) Genetic variation and differentiation within a natural community of five oak species (Quercus spp.). Plant Biology, 9, 116-126. doi:10.1055/s-2006-924542

[41] Du, J.X., Wang, X.F. and Zhang, G.J. (2007) Leaf shape based plant species recognition. Applied Mathematics and Computation, 185, 883-893. doi:10.1016/j.amc.2006.07.072

[42] Kremer, A., Dupouey, J.L., Deans, J.D., Cottrell, J., Csaikl, U., Finkeldey, R., Espinel, S., Jensen, J., Kleinschmit, J., Dam, B.V., Ducousso, A., Forrest, I., Heredia, U.L.D., Lowe, A.J., Tutkova, M., Munro, R.C., Steinhoff, S. and Badeau, V. (2002) Leaf morphological differentiation between Quercus robur and Quercus petraea is stable across western European mixed oak stands. Annals of Forest Sciences, 59, 777-787. doi:10.1051/forest:2002065
[43] WinFolia (2007) Image analysis for plant science. Regent Instruments Inc., Nepean.

[44] Weather Environment Canada (2010) weather.gc.ca

[45] De Martonne, E. (1926) L'indice d'aridité, Bull, Ass. Geogr. France. In EURAC-Institute for applied remote sensing. (2011) Synthesis report-CLISP-Climate change adaptation by spatial planning in the alpine space.

[46] Migalina, S.V., Ivanova, L.A. and Makhnev, A.K. (2009) Size of the leaf as a marker of birch productivity at a distance from the climatic optimum. Russian Journal of Plant Physiology, 56, 858-862.

[47] Sjors, H. (1974) Ekologisk klimatlara. Vaxtbiologiska Institutionen Uppsala, Uppsala.

[48] Hovenden, M.J. and Schoor, J. (2004) Nature vs nurture in the leaf morphology of Southern beech, Nothofagus cunninghamii (Nothofagaceae). The New Phytologist, 161, 585-594. doi:10.1046/j.1469-8137.2003.00931.x

[49] Teklehaimanot, Z., Lanek, J. and Tomlinson, H.F. (1998) Provenance variation in morphology and leaflet anatomy of Parkia biglobosa and its relation to drought tolerance. Trees, 13, 96-102. doi:10.1007/PL00009742

[50] Hughes, A.R., Stachowicz, J.J. and Williams, S.L. (2009) Morphological and physiological variation among seagrass (Zostera marina) genotypes. Oecologia, 159, 725733. doi:10.1007/s00442-008-1251-3

[51] Wilson, P.J., Thompson, K.E.N. and Hodgson, J.G. (1999) Specific leaf area and leaf dry matter content as alternative predictors of plant strategies. New Phytologist, 143, 155-162. doi:10.1046/j.1469-8137.1999.00427.x

[52] Lovett, P.N. and Haq, N. (2000) Diversity of the sheanut tree (Vitellaria paradoxa C.F. Gaertn.) in Ghana. Genetic Resources and Crop Evolution, 47, 293-304. doi:10.1023/A:1008710331325

[53] Wright, I.J. and Westoby, M. (1999) Differences in seedling growth behaviour among species: Trait correlations across species, and trait shifts along nutrient compared to rainfall gradients. Journal of Ecology, 87, 85-97. doi:10.1046/j.1365-2745.1999.00330.x

[54] Yates, M.J., Anthony Verboom, G., Rebelo, A.G. and Cramer, M.D. (2010) Ecophysiological significance of leaf size variation in Proteaceae from the Cape Floristic Region. Functional Ecology, 24, 485-492. doi:10.1111/j.1365-2435.2009.01678.x

[55] Fonseca, C.R., Overton, J.M., Collins, B. and Westoby, M. (2000) Shifts in trait-combinations along rainfall and phosphorus gradients. Journal of Ecology, 88, 964-977. doi:10.1046/j.1365-2745.2000.00506.x

[56] Reich, P.B., Ellsworth, D.S. and Walters, M.B. (1998) Leaf structure (specific leaf area) modulates photosynthesis-nitrogen relations: Evidence from within and across species and functional groups. Functional Ecology, 12, 948-958. doi:10.1046/j.1365-2435.1998.00274.x

[57] Xu, Z.Z. and Zhou, G.S. (2006) Combined effects of water stress and high temperature on photosynthesis, nitrogen metabolism and lipid peroxidation of a perennial grass Leymus chinensis. Planta, 224, 1080-1090. doi:10.1007/s00425-006-0281-5

[58] Tomlinson, K.W., Poorter, L., Sterck, F.J., Borghetti, F., 
Ward, D., de Bie, S. and van Langevelde, F. (2013) Leaf adaptations of evergreen and deciduous trees of semi-arid and humid savannas on three continents. Journal of ECOgy, 101, 430-440. doi:10.1111/1365-2745.12056

[59] Farley, R.A. and McNeilly, T. (2000) Diversity and divergence in Cistus salvifolius (L.) populations from contrasting habitats. Hereditas, 132, 183-192.

[60] Johnson, H.B. (1975) Plant pubescence: An ecological perspective. Botanical Review, 41, 233-258. doi:10.1007/BF02860838

[61] Dudley, S.A. (1996) Differing selection on plant physiological traits in response to environmental water availability: A test of adaptive hypotheses. Evolution, 50, 92102. doi: $10.2307 / 2410783$

[62] Givnish, T.J. (1979) On the adaptive significance of leaf form. In: Solbrig, O.T., Jain, S., Johnson, G.B. and Raven, P.H., Eds., Topics in Plant Population Biology, Columbia
University Press, New York, 375-407.

[63] Roy, B.A., Stanton, M.L. and Eppley, S.M. (1999) Effects of environmental stress on leaf hair density and consequences for selection. Journal of Evolutionary Biology, 12, 1089-1103.

[64] Ehleringer, J. (1982) The Influence of water stress and temperature on leaf pubescence development in Encelia farinosa. American Journal of Botany, 69, 670-675. doi: $10.2307 / 2442956$

[65] Schuepp, P.H. (1993) Tansley review No. 59. Leaf boundary layers. New Phytologist, 125, 477-507. doi: $10.2307 / 2442956$

[66] Pearce, D.W., Millard, S., Bray, D.F. and Rood, S.B. (2006) Stomatal characteristics of riparian poplar species in a semi-arid environment. Tree Physiology, 26, 211-218. doi:10.1093/treephys/26.2.211 